\title{
HUBUNGAN PENGETAHUAN, SIKAP DAN PERILAKU IBU HAMIL TERHADAP KETIDAKPATUHAN DALAM MENGKONSUMSI TABLET TAMBAH DARAH DI PUSKEMAS PURWOKERTO BARAT BANYUMAS
}

\author{
Alfi Noviyana ${ }^{1}$ Citra Hadi Kurniati ${ }^{2}$ \\ alfinovi13@gmail.com \\ ${ }^{1,2}$ Prodi Kebidanan DIII Fakultas Ilmu Kesehatan, Universitas Muhammadiyah Purwokerto Jln Letjen Soepardjo \\ Roetam Km 7 Sokaraja, Purwokerto
}

\begin{abstract}
ABSTRAK
Sampai saat ini anemia masih merupakan masalah gizi utama yang diderita oleh ibu hamil. Namun program pemberian tablet besi pada wanita hamil yang menderita anemia kurang menunjukan hasil yang nyata disebabkan oleh kepatuhan minum tablet besi yang tidak optimal dan status besi Wanita Usia Subur (WUS) sebelum hamil sangat rendah,

Tujuan Penelitian mengetahui hubungan pengetahuan, sikap dan perilaku terhadap ketidakpatuhan ibu hamil dalam mengkonsumsi tablet tambah darah di puskesmas Purwokerto Barat. Jenis Penelitian analitik observasional, Desain penelitian ini adalah cross sectional, Jumlah sampel 30 dilaksanakan di Puskesmas Purwokerto Barat Kabupaten Banyumas, analisis univariat untuk menghitung distribusi frekuensi, analisis bivariat untuk melihat apakah ada hubungan antara variabel dependen dengan variabel dengan analisis Fisher's Exact Test. Hasil penelitian ini bahwa 40\% responden tidak patuh mengkonsumsi Tablet Tambah Darah (TTD), dua variabel yang terbukti secara statistik memiliki hubungan yang bermakna dengan ketidakpatuhan ibu dalam mengkonsumsi TTD yakni sikap dan perilaku ibu hamil dengan p value 0.000. Kesimpulan : pengetahuan secara statistik tidak berhubungan dengan ketidakpatuhan ibu hamil dalam mengkonsumsi TTD, sedangkan sikap dan perilaku ibu yang berhubungan.
\end{abstract}

Kata Kunci : Ketidakpatuhan, Tablet tambah darah

\section{Pendahuluan}

Setiap ibu hamil diharapkan dapat menjalankan kehamilannya dengan sehat, bersalin dengan selamat, serta melahirkan bayi yang sehat. Ada beberapa masalah yang dapat mempengaruhi kehamilan, pertumbuhan janin dan bahkan dapat menimbulkan komplikasi kehamilan dan persalinan, mempengaruhi pertumbuhan dan perkembangan janin serta mengancam kehidupan ibu dan bayi seperti kurang energi kronis, anemia, kurang yodium, HIV/AIDS, malaria.

Sampai saat ini anemia masih merupakan masalah gizi utama yang diderita oleh ibu hamil dan wanita pada umumnya. Anemia pada ibu hamil meningkatkan risiko terjadinya keguguran, lahir sebelum waktunya, melahirkan bayi dengan Berat Badan Lahir Rendah (BBLR), lahir mati dan kematian perinatal. Ibu hamil yang menderita anemia dapat mengalami kegagalan jantung, yang dapat menimbulkan kematian. ${ }^{1}$

World Health organization (WHO) di tahun 2012 memperkirakan 41,8\% wanita hamil didunia mengalami anemia defisiensi besi, data Riskesdas tahun 2013 menunjukkan $37,1 \%$ ibu hamil anemia, data dari Dinas Kesehatan Kabupaten Banyumas pada tahun 2015 prevalensi ibu hamil dengan anemia di kabupaten banyumas mencapai $42,1 \%$. Penanggulangan anemia pada ibu hamil dilaksanakan dengan program pemberian tablet $\mathrm{Fe}$ kepada ibu hamil selama kehamilannya. $^{2}$

Peraturan Menteri Kesehatan Republik Indonesia (Permenkes RI) nomor 88 tahun 2014 tentang standar Tablet Tambah Darah (TTD) bagi wanita subur dan ibu hamil, menerangkan bahwa TTD bagi wanita usia subur dan ibu hamil sekurangnya mengandung zat besi setara dengan $60 \mathrm{mg}$ besi elemental (dalam bentuk sediaan Ferro Sulfat, Ferro Fumarat atau Ferro Gluconat) dan ibu hamil diberikan setiap hari selama masa kehamilannya atau minimal 90 (sembilan puluh) tablet. WHO juga merekomendasikan untuk pemberian tablet tambah darah 30-60 mg/hari elemen 
zat besi selama kehamilan dan lebih baik apabila diberikan lebih awal.

Namun program pemberian TTD pada wanita hamil yang menderita anemia kurang menunjukan hasil yang nyata. Hal ini disebabkan oleh dua hal yaitu kepatuhan minum tablet besi yang tidak optimal dan status besi Wanita Usia Subur (WUS) sebelum hamil sangat rendah, sehingga jumlah tablet besi yang dikonsumsi tidak cukup untuk meningkatkan Hemoglobin (Hb) dan simpanan besi. ${ }^{3}$

Data nasional Ibu hamil yang menerima obat tambah darah mencapai 90 $\%$ tapi kepatuhan minum obat anemia hanya 18\%. Cakupan ibu hamil di kabupaten Banyumas yang mendapatkan tablet pada kunjungan pertama kehamilan (Fe 1) 2015 sebanyak 98,11\%, mengalami kenaikan dari tahun 2014 sebanyak 94,34 $\%$ dan cakupan $\mathrm{Fe} 3$ pada tahun 2015 sebanyak 94,88\%. Data di puskesmas Purwokerto Barat cakupan Fe 1 sebanyak 99\% dan $\mathrm{Fe} 3$ mencapai 97\%. Namun prevalensi anemia ibu hamil masih tinggi.

Dalam penelitian Ratnawati faktorfaktor yang mempengaruhi kepatuhan ibu hamil dalam mengkonsumsi tablet besi (tablet $\mathrm{Fe}$ ) antara lain faktor predisposisi yang mencakup pengetahuan dan sikap masyarakat terhadap kesehatan, tradisi dan kepercayaan masyarakat terhadap hal-hal yang berkaitan dengan kesehatan, sistem nilai yang dianut masyarakat, tingkat pendidikan dan tingkat sosial ekonomi, kemudian faktor pendukung yang terdiri dari ketersediaan fasilitas dan sarana Fe, ketersediaan tablet Fe, ketersediaan tablet besi, dan faktor penguat yaitu perilaku petugas kesehatan dan peran serta keluarga. ${ }^{4}$

Tingkat

pengetahuan mempengaruhipemenuhan kebutuhan TTD selama hamil. Pengetahuan akan menentukan sikap dan perilaku ibu dalam mengkonsumsi TTD. Hasil Penelitian oleh Kartikasari menunjukkan bahwa ada hubungan antara pengetahuan dan sikap ibu hamil dengan perilaku keteraturan mengkonsumsi tablet Fe. Ketidakpatuhan juga merupakan salah satu dampak dari ketidaktahuan ibu hamil mengenai pentingnya asupan selama kehamilan. ${ }^{5,6}$
Dari fenomena diatas penulis tertarik untuk melaksanakan penelitian untuk mengetahui hubungan antara pengetahuan, sikan dan perilaku terhadap ketidakpatuha ibu hamil dalam mengkonsumsi tablet tambah darah.

\section{Metode Penelitian}

Penelitian ini adalah observasional analitik, dengan desain cross sectional Populasi target dalam penelitian ini adalah seluruh ibu hamil trimester 3 yang berada di wilayah kerja puskesmas Purwokerto Barat. Adapun kriteria dari sampel penelitian ini adalah ibu hamil yang bersedia menjadi reponden, memeriksakan kehamilannya dan telah menerima tablet tambah darah di Puskesmas Purwokerto Barat. Teknik sampel yangdigunakan adalah Propotional Random Sampling. Didapatkan sampel 30 responden. Variabel terikat adalah ketidakpatuhan sedangkan veriabel bebas adalahpengetahuan, sikap, perilaku, kemudian karakteristik responden meliputi usia, pendidikan, pekerjaan, pendapatan dan paritas serta faktor eksternal yaitu motivasi dari tenaga kesehatan. Teknik analisis data dalam penelitian ini dilakukan secara bertahap meliputi analisis univariat untuk menghitung distribusi frekuensi, analisis bivariat untuk melihat apakah ada hubungan antara variabel dependen dengan variabel dengan analisis Fisher's Exact Test. Analisi data pada penelitian ini menggunakan bantuan soft ware.

\section{Hasil Dan Pembahasan}

Dari 30 responden, sejumlah 12 responden (40\%) masih belum patuh dalam mengkonsumsi Tablet Tambah Darah (TTD).

Berikut iniTabel 3.1 Rekapitulasi Hasil Univariat karakteristik dan variabel yang berhubungan dengan ketidakpatuhan dalam konsumsi TTD

\begin{tabular}{l|l|l|}
\hline \multicolumn{1}{|c|}{ Variabel } & N & \multicolumn{1}{c|}{$\%$} \\
\hline Umur & & \\
Usia berisiko & 8 & 26.67 \\
Usia reproduksi sehat & 22 & 73.33 \\
\hline
\end{tabular}

Pendidikan 


\begin{tabular}{lll} 
Tinggi & 21 & 70 \\
Rendah & 9 & 30 \\
\hline Pekerjaan & 9 & 30 \\
Bekerja & 21 & 70 \\
Tidak Bekerja & & \\
\hline Pendapatan & 7 & 23.33 \\
Rendah & 23 & 76.67 \\
Tinggi & & \\
\hline Paritas & 12 & 40 \\
Primigravida & 18 & 60 \\
Multigravida & & \\
\hline Pengetahuan & 14 & 46.67 \\
Baik & 16 & 53.33 \\
Kurang & & \\
\hline Sikap & 18 & 60 \\
Positif & 12 & 40 \\
\hline Negatif & & \\
\hline Perilaku & 18 & 60 \\
Baik & 12 & 40 \\
\hline Kurang baik & & \\
\hline
\end{tabular}

Tabel 3.2Rekapitulasi hasil Bivariat ketidakpatuhan dalam konsumsi TTD

\begin{tabular}{|c|c|c|c|c|c|}
\hline \multirow{3}{*}{ Variabel } & \multicolumn{4}{|c|}{ Kepatuhan Konsumsi TTD } & \multirow{3}{*}{$\begin{array}{c}P \\
\text { Value }\end{array}$} \\
\hline & \multicolumn{2}{|c|}{ Patuh } & \multicolumn{2}{|c|}{ Tidak } & \\
\hline & $\mathrm{n}$ & $\%$ & $\mathrm{n}$ & $\%$ & \\
\hline \multicolumn{6}{|c|}{ Pengetahuan } \\
\hline Baik & 11 & 78.6 & 3 & 21.4 & 0.072 \\
\hline Kurang & 7 & 43.8 & 9 & 56.3 & \\
\hline \multicolumn{6}{|l|}{ Sikap } \\
\hline Positif & 17 & 94.4 & 1 & 7.2 & 0.000 \\
\hline Negatif & 1 & 7.2 & 11 & 91.7 & \\
\hline \multicolumn{6}{|l|}{ Perilaku } \\
\hline Baik & 17 & 94.4 & 1 & 7.2 & 0.000 \\
\hline Kurang & 1 & 7.2 & 11 & 91.7 & \\
\hline
\end{tabular}

Hasil penelitian ini yang dilakukan pada 30 responden di wilayah puskemas Purwokerto Barat menunjukkan responden yang patuh mengkonsumsi tablet tambah darah (TTD) sebanyak $60 \%$, sedangkan masih ada $40 \%$ yang tidak patuh mengkonsumsi TTD. Hal ini berarti masih banyak ibu hamil yang tidak patuh mengkonsumsi TTD meskipun TTD diberikan kepada ibu hamil secara gratis hal ini dapat dilihat bahwa cakupan $\mathrm{Fe} 3$ dipuskesmas purwokerto barat yang sudah mencapai target yang ditetapkan oleh Dinas Kesehatan Banyumas. Hasil Riskesdas 2010 menunjukkan bahwa masih ada 19,3\% ibu hamil yang tidak minum tablet FE dan hanya $18 \%$ yang minum tablet $\mathrm{Fe} 90$ tablet atau lebih. Banyak penelitian yang menunjukkan bahwa tingkat ketidakpatuhan ibu hamil untuk minum TTD masih rendah diatas.
Rendahnya kepatuhan ibu hamil dalam mengkonsumsi suplemen besi merupakan suatu penyebab angka prevalensi anemia masih tetap tinggi Dari penelitian yang dilakukan di Puskesmas di Yogyakarta, sekitar 40\%-50\% ibu tidak patuh minum tablet Fe. Sejalan dengan penelitian Wipayani di Semarang, dari 30 orang responden, masih terdapat 30\% diantaranya tidak patuh minum tablet $\mathrm{Fe}^{7-}$ 9

Hasil dalam penelitian ini 53,33\% responden memiliki tingkat pengetahuan yang kurang tentang TTD, Hasil analisis statistik menunjukkan bahwa tidak ada hubungan antara pengetahuan dengan ketidakpatuhan mengkonsumsi tablet tambah darah. Sebanyak 56,3\% responden dengan pengetahuan kurang tidak patuh dalam mengkonsumsi TTD namun 76,8\% responden dengan tingkat pengetahuan baik patuh dalam mengkonsumsi TTD, Hal ini sesuai dengan pendapat Mediana bahwa ibu hamil dengan pengetahuan baik lebih lebih patuh mengkonsumsi TTD dibandingkan ibu hamil yang memiliki pengetahuan kurang. Tingkat pengetahuan seseorang mengenai tablet Fe berpengaruh terhadap perilaku dalam memilih makanan yang mengandung zat besi. Hal ini sejalan juga dengan penelitian yang dilakukan oleh Sri di Bantul, menyebutkan bahwa ibu hamil yang memiliki pengetahuan mengenai anemia yang cukup baik belum dapat mendorong ibu hamil untuk lebih patuh mengonsumsi tablet $\mathrm{Fe}$ akan tetapi terdapat kecenderungan bahwa sebagian besar ibu hamil yang patuh memiliki pengetahuan yang baik. ${ }^{10,11}$

Hasil penelitian ini menunjukkan bahwa sikap dan perilaku responden menunjukkan $60 \%$ sikap yang positif dan perilaku baik, $40 \%$ sisanya responden dengan sikap yang negatif dan perilaku yang kurang baik terhadap konsumsi TTD. Hasil analisis statistik juga menunjukkan bahwa ada hubungan antara sikap dan perilaku responden terhadap ketidakpatuhan dalam mengkonsumsi TTD dengan $p$ value $=0.000$. Responden yang mempunyai sikap dan perilaku negatif cenderung tidak patuh dalam mengkonsumsi TTD. 
Sikap negatif dari responden dengan mengabaikan maksud, tujuan dan manfaat dari TTD memperlihatkan ketidakpatuhan responden terhadap TTD, begitu pula perilaku responden yang kurang baik seperti tidak mengindahkan aturan dalam mengkonsumsi tablet tambah darah merupakan faktor yang mempengaruhi ketidakpatuhan responden dalam mengkonsumsi TTD. ${ }^{12}$

Hasil penelitian Ratnawati, menunjukkan bahwa 50\% responden memiliki sikap yang kurang baik dalam mengkonsumsi tablet $\mathrm{Fe}$, hal ini disebabkan oleh sikap ibu hamil yang kurang memahami pentingnya mengkonsumsi tablet $\mathrm{Fe}$ serta dampak yang ditimbulkannya. Faktor yang mempengaruhi sikap diantaranya minat dari dalam sendiri dan dapat pula dipengaruhi oleh informasi yag ibu hamil peroleh dari majalah, televisi ataupun dari tenega kesehatan mengenai konsum si tablet Fe. Hasil penelitian tersebut didukung oleh penelitian Budiarini bahwa $60 \%$ respoden mempunyai sikap yang kurang baik atau tidak patuh tidak patuh dalam mengkonsumsi tablet Fe. penyebab ketidakpatuhan responden pada penelitian tersebut selama mengkonsumsi tablet $\mathrm{Fe}$ adalah adanya efek samping yang dialami oleh ibu hamil selama mengkonsumsinya, yakni rasa mual, konstipasi dan perubahan warna tinja. ${ }^{4,12,13}$

Hasil penelitian ini sejalan dengan penelitian Ratnawati yakni 55,2\% responden mempunyai perilaku buruk dalam mengkonsumsi tablet tambah $\mathrm{Fe}$, hal ini disebabkan karena responden tidak paham tentang pengaruh tablet $\mathrm{Fe}$ pada janin. Namun Hasil penelitian Apringsih menunjukkan bahwa 69,3\% responden memiliki praktik mengkonsumsi tablet $\mathrm{Fe}$ yang baik, hal ini didukung oleh tingkat pendidikan responden yang tinggi, tingkat pengetahuan dan sikap yang baik terhadap konsumsi Tablet $\mathrm{Fe}$ atau TTD. Perilaku yang paling dominan yang mempengaruhi kepatuhan ibu hamil untuk mengkonsumsi TTD adalah pengetahuan. Pengetahuan memiliki peranan yang penting dalam menentukan sikap dan perilaku mengkonsumsi tablet Fe pada ibu hamil. Namun dalam penelitian ini, tidak ada hubungan antara tingkat pengetahuan dengan ketidakpatuhan ibu hamil dalma mengkonsumsi TTD. Pada penelitian ini sikap dan perilaku yanng ditunjukkan responden adalah lupa untuk mengkonsumsi TTD dan Rasa bosan terhadap TTD karena harus dikonsumsi setiap hari. ${ }^{4,14}$

\section{Kesimpulan}

Penelitian ini menghasilkan beberapa kesimpulan antara lain :

a. 30 ibu hamil trimester III di Puskesmas Purwokerto Barat yang menjadi responden $40 \%$ diantaranya tidak patuh dalam mengkonsumsi tablet tambah darah

b. Tidak terdapat hubungan antara pengetahuan dengan ketidakpatuhan ibu hamil dalam mengkonsumsi Tablet Tambah Darah (TTD), namun terdapat hubungan antara faktor sikap dan perilaku dengan ketidakpatuhan ibu hamil dalam mengkonsumsi Tablet Tambah Darah (TTD)

\section{Daftar Pustaka}

[1] Depkes RI. 2008.Pedoman operasional penanggulangan anemi gizi di Indonesia.Jakarta : Direktorat Jendral Pembinaan Kesehatan Masyarakat

[2] Pemerintah Kabupaten Banyumas, 2015, Profil Kesehatan Kabupaten Banyumas, Dinas Kesehatan Kabupaten Banyumas

[3] Dirjen Bina Gizi dan Kesehatan Ibu dan Anak, Kemenkes RI. ,2015,Pedomanpenatalaksanaan pemberian tablet tambah darah. Jakarta : Dirjen Bina Gizi danKesehatan Ibu dan Anak, Kemenkes RI

[4] Ratnawati , Fida Puspasari. Saryono, \& Dian Ramawati, 2008, Faktorfaktor Yang Mempengaruhi Kepatuhan Ibu Hamil Dalam Mengkonsumsi Tablet Besi di Desa Sokaraja Tengah Kecamatan Sokaraja Kabupaten Banyumas. JurnalKeperawatan Soedirman (Soedirman Journal of Nursing) [online] Volume 3(3) : 114 -124

[5] Kartikasari, M.N.D. 2010. Hubungan AntaraPengetahuan

Dan 
SikapTentangAnemia

DenganKeteraturanMengkonsumsi

FE PadaIbu Hamil Di

BPSSriLumintu Surakarta".

Surakarta Universitas Sebelas Maret

[6] Mulyati. 2009. Faktor- faktor yang berhubungan dengan kepatuhan dalam mengkonsumsi tablet besi di RSUD Arifin Nu'Mang Kabupaten Sigrap. Media Kesehatan. 4: 1

[7] Mardiana, 2004. Faktor -Faktor Yang Berhubungan Dengan Kepatuhan Ibu Hamil Mengkonsumsi Tablet Besi Di Puskesmas Soko Dan Puskesmas Multi Wahana Kecamatan Soko Kota Palembang, Depok: Tesis FKM UI

[8] Rante, M.T . 2011. Analisis FaktorFaktor Yang Berhubungan Dengan Kepatuhan Ibu Hamil Minum TTD (Fe) Di Wilayah Puskesmas Kecamatan Sa'dan Malimbong Kebupaten Toraja Utara Propinsi Sulawesi Selatan. Depok : Skripsi FKM UI

[9] Aditianti, Yurista Permanasari, dan Elisa Diana Julianti. 2015. Pendampingan minum tablet tambah darah (TTD) dapat meningkatkan kepatuhan konsumsi (TTD) pada ibu hamil anemia, Penelitian Gizi dan Makanan, 38 (1): 71-78

[10] Kamidah . 2015. Faktor - Faktor Yang Mempengaruhi Kepatuhan Ibu Hamil Mengkonsumsi Tablet Fe Di Puskesmas Simo Boyolali. Gaster , 12 (1) : 36-45

[11] Handayani, 2013, Peran Petugas Kesehatan Dan Kepatuhan Ibu Hamil Mengkonsumsi Tablet Besi, Kesmas, 7(2) : pp. $55-11$

[12] Purwaningsih, Sri. 2004. Analisis faktor- faktor tang mempengaruhi kepatuhan ibu hamil dalam mengkonsumsi tablet Fe, http://ejournal.undip.ac.id/ index.php/ jnc.diakses 13 Juli 2016

[13] Budiarni, Widya , Hertanto, Wahyu Subagio. 2012. Hubungan Pengetahuan, SikapdanMotivasi Dengan Kepatuhan Konsumsi Tablet Besi Folat Pada Ibu Hamil.Journal of Nutrition College, 1(1) : 1-10

[14] Aprinigsih. 2012. Asosiasi Perilaku Ibu Hamil Dalam meminum Tablet
Zat Besi dengan Kejadian Anemia Besi Dipuskesmas X, Skripsi, UPN Veteran Jakarta 